\title{
LIVERPOOL SUB-CENTRE: CHAIRMAN'S ADDRESS
}

\author{
By B. Welbourn, Member.
}

(Address delivered at Liverpool, 6th November, 1922.)

During the year it has been my privilege to pay a second visit to Canada and the United States, and to see for myself the immense progress which has taken place in all things electrical during the past 15 years.

\section{TELEPHONY.}

The first thing that impressed me was the extensive use of the telephone both for short and long-distance work. Owing to the high price of labour and the shortage of domestic servants, the telephone is a necessity in the majority of homes. The lady of the house has much of the housework to do and necessarily gives her orders to the tradesmen by telephone. In the hotels there is not entire privacy, as even in the bedroom there is usually a telephone.

There are now approximately 14300000 telephone stations in the United States. Of these, about 850000 are on the Strowger system as made in Liverpool, and about 40000 are of other types. The annual growth of all stations is 6 per cent, but it is significant that the annual growth of automatic stations is approximately 10 per cent. The telephone companies, of which the Bell System is by far the largest, make it easy for people to telephone or telegraph, and the use of both methods has become almost a habit. As illustrating the extent of the use of the telephone, I was told in Chicago that there is one telephone to every five people, while in Los Angeles, California, with 700000 people, there are over 170000 telephones, i.e. one to every four people, and telephones are there being connected up at the rate of 290 per working day with no sign of finality ahead. To many Liverpool engineers a very interesting feature of this will be that the whole system in Los Angeles is being converted to the Strowger automatic system as quickly as the plant can be delivered from Chicago. It was also interesting to learn that two exchanges are being equipped in New York with automatic telephones.

Long-distance telephony has made considerable progress, and it is now possible to telephone from Catalina Island, off the Pacific Coast, to Havana in the island of Cuba. This telephone transmission is of more than ordinary interest, as wireless telephony is used between Catalina Island and the Californian coast and is there joined in series with the land line to the Atlantic coast whence messages pass over the loaded submarine cable to Cuba-a distance of approximately 4000 miles. I understand that, for this purpose, both the physical and phantom circuits are used over the land trunk lines.

Very severe gales with snow. are experienced in the Eastern States, and the consequent disorganization of service in the winter is having the same effect as in England, namely, the placing of main transmission circuits underground with paper-insulated lead-sheathed cables to which Pupin loading coils and thermionic valve repeaters are attached, while experiments have shown that it is now possible to telephone experimentally over 15000 miles of such loaded underground circuits, although the present commercial limit is about 1000 miles.

One very noticeable feature in telephone work in America is the free way in which lead-sheathed cables are used overhead. In these cases the lead sheath is alloyed with 1 per cent of antimony to harden it and to improve the crystalline structure, and the cable is then suspended from a messenger wire by short supports at frequent intervals.

Among the interesting things shown to me were the first coil of wire through which the late Dr. Alexander Graham Bell sent his first telephone message, and the loud-speaking telephones used by President Harding when addressing a crowd of 100000 people at the Unknown Soldier's funeral at Arlington Cemetery. Simultaneously, by means of special arrangements, he addressed audiences of similar size at San Francisco and New York. There appears to be no real technical difficulty in speaking simultaneously to audiences wherever there are telephone exchanges.

\section{BROADCASTING.}

Owing to the early lack of control in broadcasting stations, of which there are about 500, affairs seem to be in a chaotic state in the United States, and admiration was expressed for the leisurely but orderly way in which the matter is being tackled in this country.

It is estimated that there are about 2000000 wireless telephone reception sets in the United States, of which one half have been made by manufacturers and one half by amateurs. The manufacture appears to have outgrown the demand and the makers were said to be loaded up with unsaleable stock. Whether this was due to a seasonal slackness of demand, or to the interest in wireless telephony dying out, remains to be seen. It seems significant, however, that a good deal of secondhand wireless apparatus is being offered for sale.

In New York I had the pleasure of being present when Senator Marconi received the Franklin Medal of Honour and of hearing his address to the joint meeting of the American Institute of Electrical Engineers and the Institute of Radio Engineers. He dealt with the position of wireless telegraphy and telephony generally, and gave a good deal of information regarding his resumed experiments with $15-\mathrm{m}$ wave-length telephony, with which he can now get commercial speech over a distance of 120 miles, together with very close direction. It would seem that the use of such a system, which 
is outside the ordinary commercial range of wavelengths, should have considerable possibilities for ship-to-ship and ship-to-shore work and also in public utility work, as considerable secrecy can be obtained. The advantages of ship-to-ship and ship-to-shore work under foggy conditions seem to be too obvious to need argument.

\section{ELECTRICITY SUPPLY.}

I hope to say something here which will encourage and stimulate electricity supply engineers to further efforts in promoting the use of electricity in this country.

To show the extent to which electricity is used for lighting in the United States and in Canada, I would mention that in the month succeeding my departure from Liverpool I saw only a single gas flare used for illuminating purposes; that was in connection with some suburban street lighting about 10 miles from Chicago. I did not, I think, see it again during the succeeding 25 days, except in the streets of Pittsburgh, Pa., where there is ample natural gas, and until I saw it from the Elevated Railway in New York through an open window of some old property.

The New York Edison Company alone has 600000 $\mathrm{kW}$ of plant installed, and in Chicago the Commonwealth Edison Company has $626450 \mathrm{~kW}$, of which $230000 \mathrm{~kW}$ is in the Fisk-street station. The maximum demand in this city was well over $500000 \mathrm{~kW}$ in Decemer 1921. With a population of 2700000 people there are 536982 consumers, of whom 425200 are residence consumers, and the total number of kilowatt-hours developed by the company in 1921 was 1928271940 , i.e. $714 \mathrm{kWh}$ per head of population. The number of new consumers added in 1921 was 62287 , and a car-load of meters alone is required per week to keep pace with the new service work. The total capital investment is $\$ 136310574$, say, $£ 30000000$.

Let us compare these figures with those for Greater London with a population of $8 \frac{1}{4}$ million people. Taking first of all the company and municipal undertakings, thus for the most part excluding all railway load, from the period 1919-1920 to 1920-1921 the total increase in the number of consumers was in round figures 25000 , bringing the total up to approximately 340000 . During the same period the increase in the plant installed was about $12000 \mathrm{~kW}$. There was an increase of nearly 40000000 in the $\mathrm{kWh}$ sold, bringing the total up to nearly 700000000 . The total capital investment now stands at about $£ 38000000$, exclusive of the amount specially invested in power houses for transportation supplies.

To the above figures we can add approximately $560000000 \mathrm{kWh}$ for the total units used for transportation, bringing the approximate total units for the last complete year to nearly 1300000000 , that is, about 155 per head of population. Comparing this with the $714 \mathrm{kWh}$ per head of population at Chicago, it will be realized at once what an immense amount of leeway has to be made up in the capital city of our country alone before the use of electricity reaches the state of development attained by our American cousins.

At the risk of wearying you, I want to drive the point home by giving you data for the whole of the State of California and a few other places for 1921.

Number of consumers in California $\quad$. $\quad 84011$

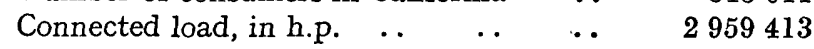

$\begin{array}{llllll}\text { Employees .. } & \text {. } & \text {. } & \text {.. } & \text {. } & 20300\end{array}$

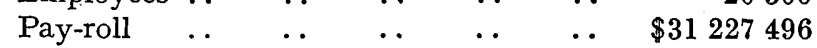
$\begin{array}{lllllll}\text { Taxes } & \ldots & \ldots & \ldots & \ldots & \ldots & \$ 6049577\end{array}$ $\begin{array}{lllllr}\text { Miles of wire } & \ldots & \ldots & \ldots & \ldots & \\ \text { Oil } & \ldots & \ldots & \ldots & 127382\end{array}$ Oil consumed-barrels (no coal or wood) 2840395

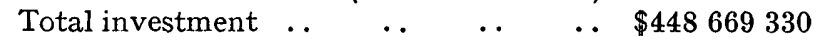
Total $\mathrm{kWh}$ generated $\quad \ldots \quad \ldots \quad \ldots 4000479010$

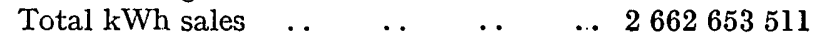
$\begin{array}{rrrrr}\text { Power plant capacity } & \ldots & \ldots & \ldots & 2662 \\ & & . & \text {. } & 1463009\end{array}$ $\begin{array}{llll}\text { Total population of States } & \text {. } & \text {. } & 3426536\end{array}$ No. of $\mathrm{kWh}$ per head of population .. $\quad 777$

In California, where the electricity supply is regulated by the Railroad Commission very much in the same way that it is governed in this country by the Electricity Commissioners, there is very little, if any, over-lapping of territory on the part of the electricity supply authorities. They seem to work together harmoniously and to have made many voluntary arrangements for the purpose of interchange of power. Practically 100 per cent of the houses in California are lighted by electricity exclusively, and, generally speaking, it may be said that the development of California depends very largely on electric power.

I should like to illustrate my meaning by giving a few particulars to show the way in which the electrical habit has been cultivated in this State. The Southern California Edison Company has 380000 h.p. installed, chiefly in hydro-electric stations, and has so much faith in the future that it is proceeding with the development of an additional 1220000 h.p. The present output is distributed over their area of 56873 square miles, with a population of 1500000 people by means of a network of over 10000 miles of transmission and distribution lines. It supplies energy for 312 communities, furnishes power for 2000 miles of interurban electric railways and for the irrigation of 1000000 acres of land. They directly supply 276000 consumers, while other Southern Californian systems supply 240000 consumers, thus making a total of 516000 .

Further north in the same State the Pacific Gas and Electric Company transmits and distributes over an area of 58481 square miles with a population of 1715959 and 285206 consumers, some of whom are distribution companies. To deal with this load, the company has a total installed capacity of $481836 \mathrm{~h} . \mathrm{p}$., of which 421750 h.p. is hydro-electric, and approximately $60000 \mathrm{~h} . p$. is steam-generated in oil-fired stations. Their supply is distributed over 9971 miles of overhead lines.

Turning to our own Empire, we find rapid development in Canada: Apart from the great systems in Quebec centring around Montreal, etc., and those in British Columbia controlled by the British Columbia Electric Railway Company, etc., there is the large Government and municipal partnership scheme called the HydroElectric Commission of Ontario, which owns and makes use of generating plant at Niagara to the extent of 427000 h.p., and other sources of power, is covering the whole province with a network of 110000 -volt 
and other lines and serves a population of 1667165 . The Commission had 268743 consumers on 3lst October, 1921, with a maximum demand in June, 1922, of 360268 h.p., and I saw for myself a great deal of the use which is made of the power from Niagara in the Commission's area from wayside farms to large undertakings such as that at Toronto. The Commission has succeeded in reducing very materially the cost of electricity to the consumer in Ontario, with the result that its use is extending rapidly. For instance, the Toronto undertaking had 12000 consumers 10 years ago, whereas it now has 80000 . In Toronto the domestic consumption in $\mathrm{kWh}$ per consumer per month was 27 in 1914 , whereas in 1921 it was 48 , an increase of 78 per cent ; the wholesale rates per $\mathrm{kWh}$ per annum have been reduced from $\$ 18.50$ in 1912 to $\$ 17.00$ in 1921 , a decrease of 8 per cent, while the net cost per $\mathrm{kWh}$ for the domestic consumer has been reduced from 4.4 cents in 19.13 to 2.2 cents in 1921 , a decrease of 50 per cent.

The question that I asked myself is : How is it that this great business is done? In the first place one would expect that the electricity supply rates for power and domestic users must be considerably lower than in this country. With the exception of the Ontario scheme just referred to, I do not think that this is the case, but members will realize that it is difficult to make a direct comparison owing to the different money values obtaining in North America and in this country. I think that the real explanation lies in the fact that the use of electricity is a habit with most people in the United States and Canada. It has to be remembered that the United States and Canada are largely new countries where gas had not become well established when electric lighting first became available, and that the growth of most of the cities has been coincident with the electrical era. In many places both the gas and electrical interests are under the control of one company with men in high position who have rightly relegated gas to its proper function of heating purposes and reserved electricity for power and lighting. The advent of electric light into the home has been followed up by very active propaganda by salesmen of electrical accessories, while the companies have extensive showrooms in which prospective consumers can see apparatus in actual use before they commit themselves to a purchase. For instance, in Chicago the whole ground floor of the Commonwealth Edison Company's large building is used for showrooms. In these showrooms I saw, among other things, an excellent demonstration of a washing machine driven by an electrical motor, not as a special demonstration but as part of the day-by-day routine.

I do not wish to create the impression that the electric supply authorities in this country are unprogressive, but the figures that $I$ have given show what an immensely greater business awaits them. Apart from railway electrification, which is only developing slowly, I would urge that much greater attention should be paid to securing the immense domestic load which may be as great as all the industrial business and less subject to trade fluctuations. This load is not to be secured by merely cutting the price of electricity, but it will require vigorous propaganda and salesmanship in the Vol. 61 . best sense of the word, the removal of all unnecessary restrictions, and arrangements to enable people to secure the apparatus without which they cannot use electricity. We are apt to forget that it is a feature of electrical appliances that their cost is frequently high compared with the value of the electricity which they consume in a year. To meet these points and to enable the electric supply undertakings to get some of the money which they now give to the gas companies and local merchants we must have :

(a) A reasonable but not necessarily a very " cut " rate for electricity.

(b) A system of hire or hire-purchase of the more expensive pieces of apparatus.

(c) In many cases, hire-purchase wiring of houses.

(d) A liberal practice in regard to

(1) Laying of mains.

(2) Showrooms:

(3) Demonstration of apparatus.

(4) Giving to the public what is generally known to-day as "service."

On the power side of the business in America most factories and the street, elevated, tube and high-speed interurban railways are run electrically, and there can be no doubt that with these already large loads a much bigger load awaits connection when the electrification of main-line railways really goes ahead. .I hope that the electricity supply authorities in this country will see to it that they secure the supply of electricity to the railways as and when the electrification of main and suburban lines is proceeded with, so that there will be no waste of capital, and so that the load factor of the supply authorities' power stations will be improved. Immense loads are provided for the supply authorities by the local and express lift or elevator systems which are used in every important office building, and there would seem to be much room for improvement in this direction in our own country. At night, large blocks of power are used by the electrical sign advertisements, and no one who has seen the "White Way" in New York is ever likely to forget it. Despite the big power loads referred to, I was very much impressed everywhere with the steadiness of the pressure supplied to the consumers' terminals. The quality of the street lighting is also for the most part quite good and, in many important streets, the light on the road surface is equal to that in Portland-street, Manchester.

A question which is often raised, and which is sometimes difficult to decide, is whether it is better to place a generating station near the centre of gravity of the load or at some distance away and to give the supply through underground or overhead mains or, alternatively, to take a supply from an outside source, with a station at a considerable distance. In one area where hydroelectric power is used extensively, some interesting data and costs were placed at my disposal. The total cost per $\mathrm{kWh}$ at the power station busbars, including all capital charges, depreciation, etc., was 0.2 cent, whereas 0.35 cent per unit have to be added to this to cover all the transmission charges over a 250-mile line to the point of delivery, making a total of 0.55 cent, so that the cost of transmission is much more important 
than the cost of generation. In this connection I was surprised to find that the power available from some hydro-electric systems fluctuates more than one had imagined it to do. In the area in question in the past 25 years the rainfall has varied from $10 \cdot 25$ to $49 \cdot 45$ inches per annum, and most of this rainfall occurs in only three months of the year. It follows from this that steam stations have to be employed on some parts of the system and, in one case, 30 per cent of the units sold last year were derived from the steam plant. The steam stations in California are usually supplied with oil fuel, the price of which fluctuates considerably. Were it not for this latter factor and the feared exhaustion of oil supplies, it is not unlikely that more use would be made of steam stations, especially as, at the average prices of oil, the total cost of generation on the Pacific Coast is just about the same as the cost of hydroelectric power delivered over such long lines as the one referred to.

In view of the great discussion in this country since 1914 on linking-up, etc., I shall naturally be expected to say something about the security of supply.

(a) A great deal of interconnection or linking-up of power systems and stations has been carried out voluntarily. Probably the outstanding example of the value of liberal linking-up was illustrated in the spring of this year, when approximately 160000 h.p. of generating plant broke down in one week in the various stations at Niagara, and yet the interruption of supply to consumers was negligible. An ounce of practice is worth pounds of theory.

(b) In big cities like New York, Chicago, San Francisco and others which have local steam stations and distribution by means of underground cables, the continuity of supply is, I believe, good. In other cities which are dependent for supply on overhead transmission lines and overhead distribution networks, the supply is not by any means so good, particularly in those districts where the overhead lines are much affected by lightning and snowstorms. The effects of snowstorms and gales were particularly felt last winter in Massachusetts, Ontario, etc., as reported in the Press at the time.

\section{TRANSMission and CABLES.}

So far as power cables are concerned, there is a good deal of experience in the United States with 24000 - and 13200 -volt, 3-core cables, and the records in the technical Press disclose that a good deal of it has not been happy. The troubles with underground cables appear to have been due both to defective manufacture and jointing and to overloading, partly under war conditions. In this connection, it has to be remembered that American engineers have mainly had to specialize in the development of overhead transmission. lines, and the question of cables has been of minor importance. They are, however, now becoming much more important, and a great deal of attention is being concentrated on the development of 3-core, high-voltage cables, including those for a working pressure of 33000 volts. The necessity for this arises out of the big loads to be transmitted and because of the attitude of the fire insurance companies towards overhead wires, especially, as so many of the residences are built of wood, and because of the hindrance caused by wires to the fire brigades before they can get to work. From this it would seem that the use of underground cables will rapidly spread in the residential areas. The long transmission lines aro a conspicuous feature of the electricity supply business in the United States and Canada, and in some places, owing to the absence of coal and oil, electricity must either be transmitted by them or not at all. They therefore have to be used, with their known susceptibility to lightning and storms. Troubles from these causes vary very much in different parts of the country. They are particularly bad in the Eastern and Middle West States, whereas on the Pacific Coast there is a noticeable absence of forked lightning and of snow, with the result that higher voltages are permissible there than elsewhere. It is right to add that there is abundant evidence that lightning troubles can be mitigated by the use of electrolytic and oxide-film arresters.

\section{Transmission Pressures.}

The Great Western Power Company in California is successfully operating at 165000 volts a.c., while the Southern California Edison Company will, next year, bring into use a 240-mile reconstructed line at 220000 volts, and the Pacific Gas and Electric Company has just brought into use at 125000 volts the Pit RiverVacaville 250 -mile line which is designed for ultimate use at 220000 volts. A great deal of the success or otherwise of transmission lines depends on the suspension-type insulators. It is notorious that these insulators were exceedingly unreliable until about five years ago and, in the interests of electricity supply generally, it is very satisfactory to know that makers in the United States and Canada, as well as one wellknown firm in this country, have very seriously tackled the problem of manufacture and have developed products which can be used with confidence. In this connection I should like to say that it is my belief that insulators built to the new B.E.S.A. Specification No. 137 (1922) can be depended on for satisfactory service, but that when next the Specification is revised a high-frequency test should be added. In order to get the best practical result from such a test, it seems desirable that the wave trains should be damped so as to simulate as closely as possible those produced by lightning.

\section{GeNERAL}

I wish to take this opportunity of acknowledging the hospitality extended to me by many engineers in the States and Canada, and to express my appreciation of the handsome way in which they placed information at my disposal. 